\title{
Present Status of Pharmacy Education and Practice in Angola: Trends and Challenges
}

\author{
Alina de las Mercedes Martínez Sánchez \\ Escuela Universitaria de Enfermería y Fisioterapia de Toledo Universidad de Castilla La Mancha,Toledo, ESPAÑA.
}

\begin{abstract}
Pharmacy education in Angola, the second largest sub-Saharan country after the Democratic Republic of Congo, has undergone some changes since the first pharmacy school was established in 2001. Currently, to practice as a pharmacist, one needs a pharmacy degree. This university degree is awarded after 5 years of pharmacy studies offered only at 7 Pharmacy Schools located mainly in the capital city. This article describes the Angolan pharmacy education framework, including criteria for admission, the type and training length and an overview of the curricula; and outlines the system of pharmacy schools. The pharmacy practice, continuing education and development barriers, and latest directions in pharmacy education are also discussed.
\end{abstract}

Key words: Angola, Curriculum, Pharmacy Education, Pharmacy practice, University.

\section{INTRODUCTION}

In Angola, to practice as a pharmacist, one needs a pharmacy degree. This university degree is awarded after 5 years of pharmacy studies offered only at 7 Pharmacy Schools located mainly in the capital city. There are three types of higher education institutions in Angola: Academies, Universities and Polytechnics. The last ones usually comprise the Pharmacy Schools.

In recent years, higher education has grown significantly in Angola: in 1979, there were 1,000 students, in 2002, after the war, there were 40,000 students, and in 2014, there were 40,095 registered students. Furthermore, there used to be only one public university. Now there are 26 public and 45 private universities. ${ }^{1,2}$ Pharmacy education in Angola, the second largest sub-Saharan country after the Democratic Republic of Congo with a population of 24,383 301 inhabitants, ${ }^{3}$ has undergone some changes since the first pharmacy school was established in 2001.

Since the Angolan economy has experienced a tremendous growth in the last few years with exports of crude oil, diamonds, and petroleum products to mainly China, the United States of America and India, due to the fast economic progression of the pharmaceutical sector, there has been an increasing need for qualified pharmacy personnel. Newly established pharmacy schools and degree programs have provided increasing opportunities for students attempting to pursue a career in pharmacy. This article describes the Angolan pharmacy education framework, including criteria for admission, the type and training length and an overview of the curricula; and outlines the system of pharmacy schools. The pharmacy practice, continuing education and development barriers, and latest directions in pharmacy education are also discussed.

\section{Pharmacy education framework}

From the historical point of view, the need for skilled pharmacists in Angola comes soon after proclamation of national independence in 1975, to bridge the void that
Submission Date : 04-01-2016 Revision Date : :29-02-2016 Accepted Date : :27-03-2016

DOI: 10.5530/ijper.50.4.6

Correspondence: Alina M. Sánchez

Campus Tecnológico Antigua Fábrica de Armas, Avda.

Carlos III, s/n., 45071 Toledo, ESPAÑA

Telf: 925268800

Fax:925268811

E-mail:alimarti2014@gmail.

com

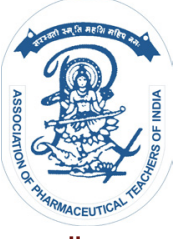

www.ijper.org 
existed in this specialty and the lack of Pharmacy Schools. Many young people with scholarships were sent abroad (Cuba, Congo, USSR, Brazil and Portugal) for a complete approved training.

Consistent with the International Pharmaceutical Federation (FIP) Education Initiative's 2013 global education report, ${ }^{3}$ Africa has the fewest pharmacists per capita in the world. According to the 2012 National Directorate of Medicines and Equipment (Direção Nacional de Medicamentos e Equipamentos) pharmacists (919) are fewer in number compared with doctors and nurses in 2004 (2 18435 nurses and 1168 physicians), ${ }^{4}$ but this number is higher than Guinea Bissau ${ }^{5}$ and Mozambique, ${ }^{6}$ (13 and 200, respectively). In the last ten years, 6 universities have opened a BPharm program, bringing the total number of BPharm programs to 7 in $2015 .^{2}$ Table 1 lists all Angolan universities currently offering the the BPharm program. Pharmacy schools are regulated by the Ministry of Higher Education. Most pharmacy schools are public-funded however, the number that is privately funded has significantly increased.

The professional pharmacist profile in Angola, could be seen through the Angolan Private Higher School of Pharmacy, which according to pharmacists is considered a generalist professional with a humanist, critical and reflective training to act in all health care levels, with scientific and intellectual rigor. ${ }^{7}$

According to 2013 data, the expected annual number of graduates was about 24 with a BPharm degree which is higher than Cape Verde, ${ }^{8}$ (4 graduates in the same year). In Angola, 381 students were registered in Pharmacy Courses in 2014. ${ }^{2}$ As developing this work, no university offers a postgraduate pharmacy program. Regarding the continuation of pharmacy education, student migration to Portugal remains a reality today. Currently, there is the increasing tendency of studying in Brazil, under exchange programs and agreements between the two countries.

\section{Conditions for admission in Pharmacy Schools}

The increasing of higher education access in Angola started by the end of the civil war (in 2002) along with the increasing in budgetary allocation for higher education. The expansion of higher education to the different provinces of the country, has contributed to the access to this level of education of a growing number of young people. In the years from 1977 to 2002, the number of higher education students increased from 1,109 to 12,566 , at an average annual rate of $10.2 \% .^{10}$

In Angola, to be eligible to enter any University program, applicants must pass a series of examinations. For example, an individual who successfully completed high school cannot enroll as an undergraduate in the Faculty of Pharmacy without passing admission exams. The competitive examination is based on questions about different topics: social, biological sciences, and health sciences. Applicants must submit original high or pre-university school certifications with itemized bills, Identity Card and Service statement; the last one only for applicant workers. Besides, the certificate of military situation regularized for candidates within the military age and three passport size photographs must be submitted. A fee must be paid as well. Figure 1 describes the admission of students to the pharmacy courses in 2014. Of the total amount of 339 admitted students, 223 were from the capital city, which has the largest number of pharmacy schools. ${ }^{2}$

Summarizing, access and quality have been identified as the two main problems of the education system in Angola. ${ }^{11}$ As said by Baptista ${ }^{12}$ each higher education institution has its own format of university admission tests, it is necessary to take into account the quality of the student who access the university. The admission exam formats should be an agreement between both, education and higher education ministries and those who enter higher education are those who graduate high school or technical high school.

\begin{tabular}{|c|c|}
\hline \multicolumn{2}{|c|}{ Table 1. Pharmacy Education Offered by Angolan Universities in $\mathbf{2 0 1 5}^{\mathbf{a}}$} \\
\hline University & Type \\
\hline Jean Piajet University & Private \\
\hline Jean Piajet de BenguelaHigher Polytechnic Institute & Private \\
\hline Atlântida Higher Polytechnic Institute & Public \\
\hline AgostinhoNeto University & Private \\
\hline Private University of Angola & Public \\
\hline Malanje Higher Polytechnic Institute & Private \\
\hline Ekuki II Humanities and Technology Higher Polytechnic Institute & Private \\
\hline
\end{tabular}

anly universities registered in the Statistical Yearbook 2014 of the Ministry of Higher Education of Angola are included. 


\begin{tabular}{|c|c|c|c|}
\hline First professional year & Hours & Third professional year & Hours \\
\hline Techniques of oral and written & 60 & Biochemistry III & 75 \\
\hline expression & 45 & Instrumental methods of analysis & 75 \\
\hline Epistemology & 60 & Pharmaceutical Organic Chemistry I & 75 \\
\hline Informatics introduction & 45 & Clinical bacteriology & 75 \\
\hline History and sociology of pharmacy & 30 & Galenic pharmacy & 75 \\
\hline Nutrition & 90 & Pharmacology II & 75 \\
\hline Mathematic I & 30 & Pharmaceutical Instrumental AnalysisII & 75 \\
\hline Public health & 45 & Pharmaceutical organic chemistry II & 75 \\
\hline General Chemistry & 60 & Biopharmaceutics and Pharmacokinetics & 60 \\
\hline Cellular and Molecular Biology & 60 & Food Science and compositional analysis & 75 \\
\hline English I & 45 & Community pharmacy & 30 \\
\hline General Physics for biosciences & 65 & Parasitology & 60 \\
\hline Pharmaceutical Inorganic Chemistry & 45 & Pharmaceutical Technology I & 75 \\
\hline General Chemistry II & 60 & & \\
\hline Laboratory Techniques & 60 & & \\
\hline Histology & 45 & & \\
\hline Dynamics of the contemporary world Human anatomy & 60 & & \\
\hline Second professional year & & Fourth professional year & \\
\hline Biochemistry I & 30 & Hydrology and hydrological analysis & 75 \\
\hline Analytical Chemistry I & 65 & Mycology & 60 \\
\hline Organic Chemistry I & 60 & Clinical Biochemistry & 60 \\
\hline General bacteriology & 60 & Epidemiology & 30 \\
\hline Botany & 60 & Pathophysiology and pharmacotherapy & 45 \\
\hline Descriptive statistics & 60 & Immunology & 45 \\
\hline Pharmacognosy & 45 & Pharmaceutical Technology II & 75 \\
\hline Human physiology & 60 & Virology & 60 \\
\hline Biochemistry II & 45 & Ethics and pharmaceutical legislation & 45 \\
\hline Analytical Chemistry II & 75 & Cosmetics & 75 \\
\hline Physical chemistry & 30 & Hospital pharmacy & 45 \\
\hline Organic Chemistry II & 75 & Pathophysiology and pharmacotherapy II & 45 \\
\hline Biogenetic & 30 & Organization and pharmaceutical Management & 45 \\
\hline Molecular biology & 60 & Pharmaceutical Technology III & 75 \\
\hline Pharmacology I & 75 & Toxicology and Toxicological Analyses & 60 \\
\hline \multirow[t]{9}{*}{ Hematology } & 60 & & \\
\hline & & Homeopathic (optional) & \\
\hline & & Pharma-toxicology (optional) & \\
\hline & & Industrial pharmaceutical biotechnology (optional) & \\
\hline & & Drug Design (optional) & \\
\hline & & Fifth professional year & \\
\hline & & Traineeship in community pharmacy & 450 \\
\hline & & traineeship in hospital pharmacy & 450 \\
\hline & & Final Thesis Project & 450 \\
\hline
\end{tabular}




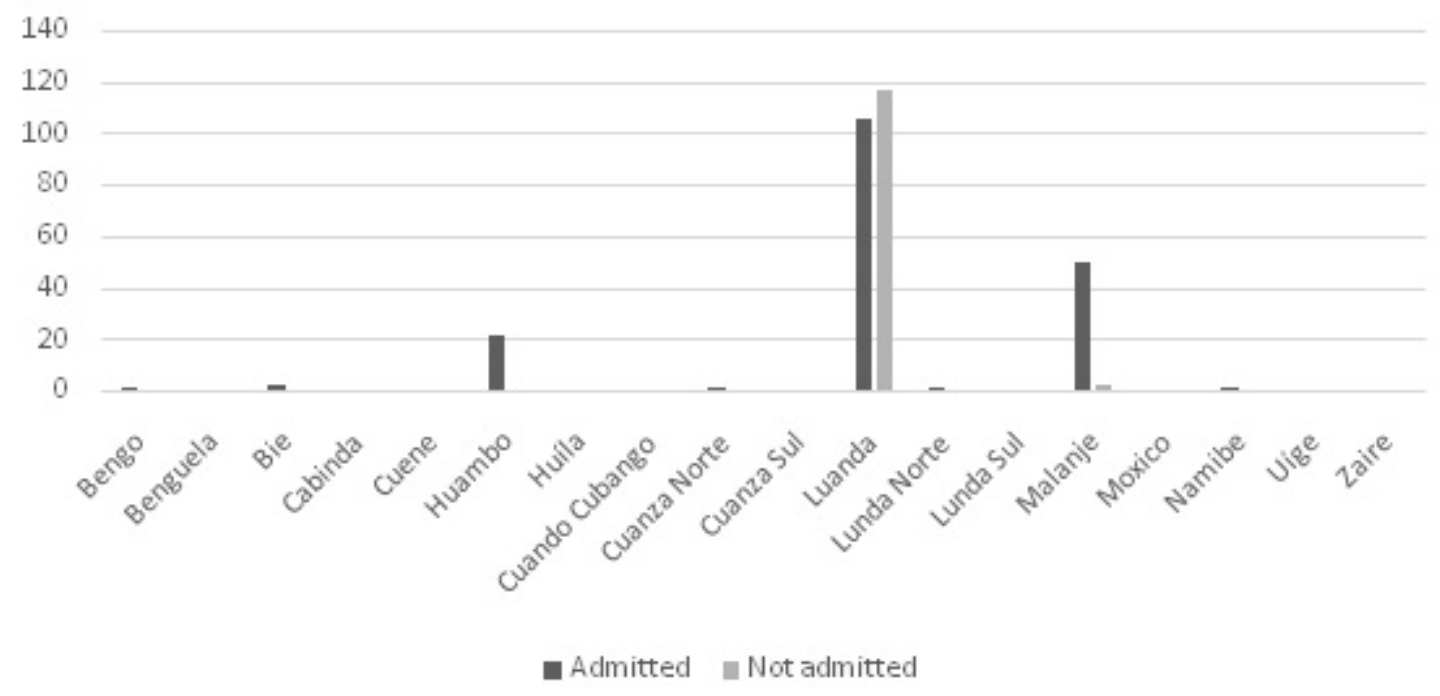

Figure 1: Admission of Students to 2014 pharmacy courses on the different provinces of Angola.

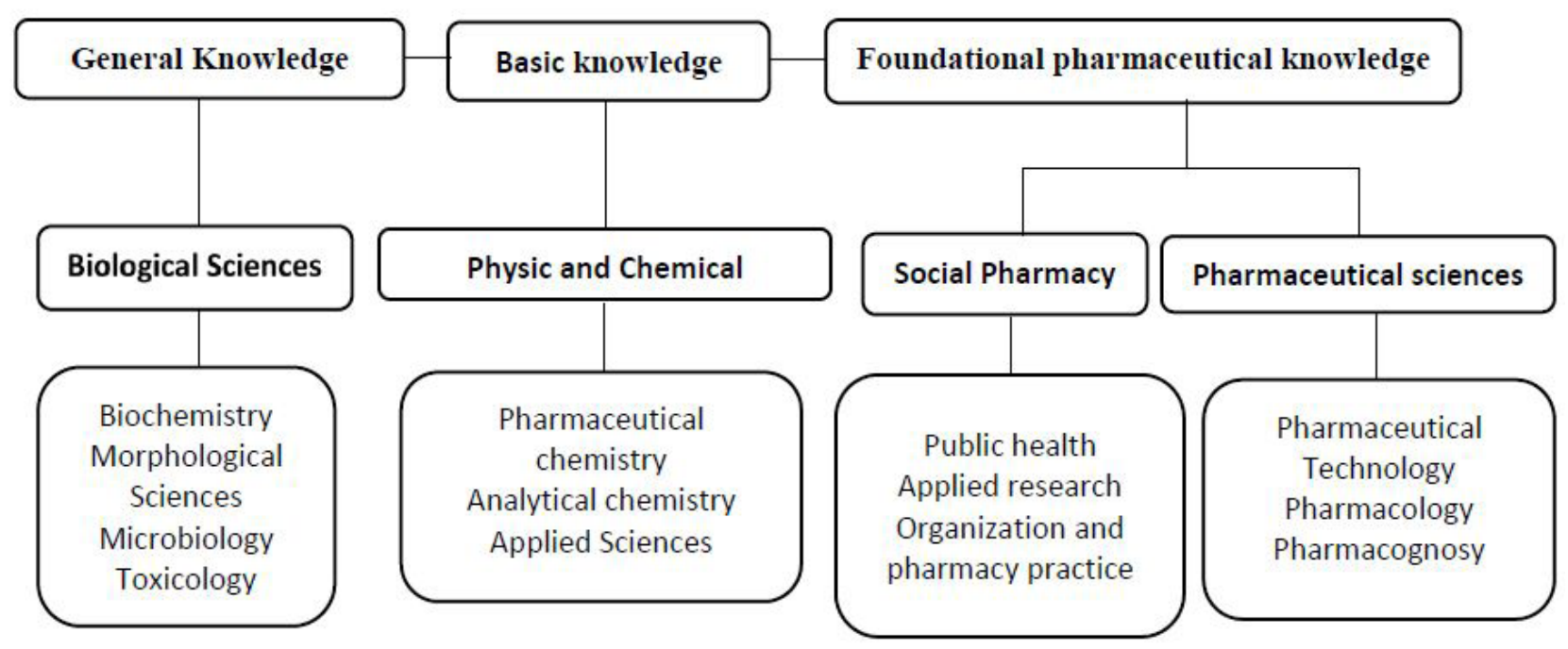

Figure 2: An overview of the BPharm Curriculum in Angola.

\section{Curriculum in Angolan Pharmacy Programs}

The emergence of various Pharmacy Schools has conditioned the rise of several teaching programs, so the establishment of Guidelines for Pharmacy Education is imperative for Angola. An approach to the pharmacy curriculum could be submitted through the Project designed by Londa et al. ${ }^{6}$ for the creation of the School of Pharmacy at Agostinho Neto University. The five year pharmacy course incorporates both theory and practice modules. Students are required to complete a unique placement in a professional setting for successful completion of the course. Each scholar year is divided into two semesters, each semester consisting of seventeen weeks. Besides, all students are required to do a research project, write a dissertation, and present their work to a scientific committee in order to graduate (Figure 2).

The pharmacy curriculum was scheduled to provide the students with all the essential information and knowledge in both basic and pharmaceutical sciences to lead them in the practice of pharmacy. Knowledge of 
the basic sciences, such as chemistry, biology, physics, and mathematics, is required for education at the college of pharmacy and for research.

Unlike Angola, other Portuguese-speaking countries such as Cape Verde ${ }^{13}$ show a pharmacy curriculum designed to strengthen pharmacy training in skills and knowledge and orient it toward clinical practice. In addition, its information concerning pharmacy education and teaching programs have greater visibility on the network. Chemical, physic, natural and environmental sciences, scientific law, pharmacy practice, mathematics, health sciences are included in the Cape Verdean pharmacy curriculum. It also ensures a knowledge of the philosophy, communication sciences, and sociology that underlie pharmacy and an understanding of the relevance of that knowledge to patient care. Table 2 lists courses taught in the Cape Verde Bachelor of Pharmacy curriculum.

\section{Education Quality Assurance}

In accordance with the research conducted by Isaac ${ }^{14}$ the development of self-evaluation in the Angolan higher education institutions is in its initial structuring phase. Certain autonomy to define their evaluation stage according to their organizational specificities, as long as that competence should be exercised without excluding the reference patterns of the national, regional and international system of evaluation. Likewise, Nascimento, ${ }^{15}$ also acknowledged that the higher education development in Angola was not followed by appropriated measures to ensure the quality of the courses and programs offered by these institutions. As expected, this reality characterizes the Angolan pharmacy education. Now-a-days, an absence of Angolan universities among the best in Africa is reported. ${ }^{16}$

In Angola, there are no Accreditation Standards and Guidelines for Pharmacy Education. Pharmacy education in Angola currently prepares pharmacy students for roles in pharmacovigilance, clinical pharmacy, hospital pharmacy, pharmacoepidemiology, clinical research and public health, herbal medicine and pharmaceutical industry. ${ }^{17}$ In 2013 is officially established the National Association of Pharmacists (Ordem dos Farmacêuticos de Angola), which has among its obligations organize internships, research, postgraduate courses, improvement and recycling as well as to promote or participate in conferences, seminars, and other activities, contributing to updating the knowledge of professionals on topics relate to pharmacy practice and other areas of health. ${ }^{18}$ Creating quality standards in pharmacy education it was considered among the obligations of this organization according to FIP, the educational development should progress through an action plan that first seeks to "identify local needs, the pharmacy services needed to meet these needs, the competences needed to provide these pharmacy services and the education required to achieve/ensure these competences". ${ }^{19}$ FIP's Pharmacy Education Action Plan is oriented toward identifying locally determined pharmacy service needs and then facilitating comprehensive educational development and competency achievements to meet those local needs.

\section{Future directions of pharmacy education}

The continuing growth of Africa's pharmaceutical industry, shortages in the number of trained pharmacists, growth access of patients to medicines previously unavailable on the continent, the rise of major cities, the expansion in healthcare capacity, and the maturing of the business environment, turns Africa into a continent of opportunity for pharmacists and patients. ${ }^{20,21}$

Some efforts to improve the system of pharmacy schools include: extending existing pharmacy schools, implementing the establishment of new pharmacy schools and increasing investment in the area; improving teaching facilities for example: classrooms, laboratories, materials, and computerized systems. Besides, when improving the quality of pharmacy education, some policies take into account the National Statement of Pharmacy Education Standards consistent with the concept of the seven-star pharmacist, introduced by the World Health Organization (WHO) and included by FIP in 2000 in its policy on Good Pharmacy Education Practice. ${ }^{22}$

Cooperation between pharmacy schools and industry helps to provide some continuing education opportunities to upgrade the knowledge and skills of the existing pharmacy workforce. Two hundred pharmacists from Luanda and other provinces were trained on generic, skin diseases, and oral hygiene topics by Tecno-Saúde Inc; likewise, during the first half of 2013, 17 pharmacy students from Jean Piajet University were trained in Portugal, within the framework of the cooperation agreements between state universities and companies like Bayer and Blue pharma respectively. ${ }^{23}$ Angola is a member of the Association of Pharmacists of Portuguese Language Countries-Associação de Farmacêuticos dos Países de Língua Portuguesa (AFPLP)-, which according to the continuous updating of knowledge and development of professional attitudes are fundamental to the advancement of the pharmacy professionals. ${ }^{24}$

As stated by Valmir Santi, ${ }^{25}$ AFPLP is committed to create an integrated pharmacy curriculum among all members, increase training opportunities and pharmacists organization and get more benefits out of the staff training process, especially at the level of continuous 
education. The experience of more advanced countries in both, the practice of patient-centered pharmacy and the stabilized pharmacy system, like Portugal, must be taken advantage of.

\section{Pharmacy practice}

In Angola, the pharmacy activity is regulated by Presidential Decree 191/10 (September 1 1 st). ${ }^{26}$ According to the decree, the Ministry of Health is responsible for the organization, legislation and oversight of the pharmacy activity. For its operation, all pharmacies are required to have the presence of a pharmacist or pharmacy technician, who is responsible for good pharmacy practices, thus being technical director. If the pharmacy has no pharmacist it can be managed by a pharmacy technician, however the pharmacy technician must be supervised by a pharmacist who is located geographically nearby. Should possess the technical direction of the pharmacy, this activity is incompatible with any other to prevent staying in the pharmacy. Currently, there are 1261 pharmacies in Angola ${ }^{27}$ covering the entire country, with one pharmacy for every 10000 inhabitants.

Related to pharmacy services, pharmacy practice in Angola is also regulated by the AFPLP Resolution, which brings together professionals from Angola, Brazil, Cape Verde, Guinea-Bissau, Mozambique, Portugal and Sao Tome and Principe, approved in General Assembly held in Luanda, Angola in 2013. ${ }^{28}$

\section{CONCLUSION}

With the rapid expansion in the number of pharmacy schools, ensuring high-quality pharmacy education is a major challenge for Angola.

Data collection on the characteristics of the pharmacy workforce and pharmacy practices, identifying the specific needs of the country, and using these to develop comprehensive education is considered as a first step towards improving the quality of pharmacy education.

Set up a national framework of pharmacy programs as guidelines for pharmacy schools to develop their own specific curricula, elaborate standard pharmacy textbooks with up-dated and advanced content, elaborate postgraduate pharmacy programs to offer continuing education and professional development chances in cooperation with overseas organizations, are some challenges to face by pharmacy education and practice in Angola in the near future.

\section{ACKNOWLEDGEMENTS}

Boaventura Moura and Eduardo Ekundi Valentim from Ordem dos Farmacêuticos de Angola and Instituto
Superior Politécnico de Malanje, respectively for their willingness to prepare this article, although it was impossible to realize their collaboration. Mr. Manuel Antonio Reyes Sampedro for his assistance during the preparation of this article.

\section{CONFLICTS OF INTEREST}

The author has no conflict of interests to declare.

\section{REFERENCES}

1. Do Nascimento A. Higher Education in Angola: The Importance of International Partnerships. January 31, 2013. http://www.chathamhouse.org/ events/view/188811. Accessed November 15, 2015.

2. Ministério do Ensino Superior. Anuário Estatístico 2014. Luanda 2014. http:// unia.ao/docs/MES_AnuarioEstatistico2014.pdf. Accessed November 16, 2015.

3. International Pharmaceutical Federation - FIP 2012 FIP Global Pharmacy Workforce Report. The Hague, The Netherlands: International Pharmaceutical Federation. 2012.

4. Angola. Health Workforce. Pharmacists. http://knoema.es/atlas/Angola/ topics/Salud/Recursos-Humanos-en-Salud/Farmac\%C3\%A9uticos?action= export\&gadget=indicator-preview-host\#_=_. Accessed November 16, 2015.

5. Guiné-Bissauem números. (c) 2005 Instituto Nacionalde Estatísticae Censos. http://www.stat-guinebissau.com/publicacao/GB_Numerofinal_ Publica\%C3\%A7\%C3\%A3o1.pdf. Accessed March 17, 2016.

6. Ordem dos Farmacêuticos (OF). http://www.ordemfarmaceuticos. $\mathrm{pt} / \mathrm{scid} /$ of Weblnst_09/default A r ticleView One. asp?category $\mid \mathrm{D}=1492 \&$ articlelD=6146. Accessed March 17, 2016.

7. Londa-Vueba $M$. Formação pré-graduada, pós-graduada $E$ contínua em Angola. IX Congresso Mundial de Farmacêuticos da Comunidade de países de Língua Portuguesa (CPLP). Praia, Cabo Verde, 24 de Abril de 2008.

8. Anuário Estatístico do Ministério de Ensino Superior, Ciência e Inovação. Cabo Verde. http://www.mesci.gov.cv/images/Anuario\%202013-14\%20 actual.pdf. Accessed March 17, 2016.

9. Liberato E. A Formação de Quadros Angolanos no Exterior: Estudantes angolanos em Portugal e no Brasil.Cadernos de Estudos Africanos. 2012;23:109-30.

10. Paulo deCarvalho. Evolução e crescimento do ensino superior em Angola Revista Angolana de Sociologia. 2012;1(9):51-8.

11. Governo da República de Angola. Estratégia Integrada para a Melhoria do Sistema de Educação 2001-2015. http://planipolis.iiep.unesco.org/upload/ Angola/Angola_Estrategia_Integrada_Melhoria.pdf. Accessed November 18, 2015.

12. Agência Angola Press (ANGOP). Ministério do Ensino Superior quer regular sistema de acesso ao ensino superior. 05 Setembro de 2013 | $18 \mathrm{~h} 09$ Atualizado em 05 Setembro de 2013 | 19h50. http://www.portalangop. co.ao/angola/pt_pt/noticias/educacao/2013/8/36/Ministerio-Ensino-Superiorquer-regular-sistema-acesso-ensino-superior,2fa78b3d-2add-48c1-8c09bb772408dce1.html. Accessed November 18, 2015.

13. Universidade Jean Piajet de Cabo Verde. Ciências Farmacêuticas. Descrição geral www.unipiaget.cv/doc/cfa.pdf. Accessed March 17, 2016.

14. Isaac O, López A, Mohar F.Higher education, Angola. Rev Cie Téc Agr. 2014;23(2):76-80.

15. ANGOP. Ministro do Ensino Superior analisa atual estado do sector. 10 Novembro de 2014 | 06h46 - Atualizado em 10 Novembro de 2014 | 08h51. http://www.portalangop.co.ao/angola/pt_pt/noticias/educacao/2014/10/46/ Ministro-Ensino-Superior-analisa-actual-estado-sector,a351c097-bb17408a-83cd-01127c565f10.html.Accessed November 16, 2015.

16. VOA-Voz da America. Ausência de universidades angolanas entre as melhores de África fere o orgulho nacional. http://www.voaportugues. com/content/angolanos-descontentes-com-ausencia-de-universidadesangolanas-no-ranking-africano/1830814.html. Accessed November 17, 2015. 
17. Kamgno J. A história do ensino farmacêutico em Angola. Revista da Ordem dos Farmacêuticos de Angola. 2014;2:25.

18. Estatuto da Ordem dos Farmacêuticos de Angola. ARTIGO $3^{\circ}$ (Atribuições). http://www.ordemfarmaceuticosangola.org/PDF/2-EstatutosOFA01042011A provadoEmenda.pdf. Accessed November 17, 2015

19. Anderson C, Bates I, Beck D, et al. The WHO UNESCO FIP Pharmacy Education Taskforce. Hum Resour Health. 2009;7(1):45. http://dx.doi. org/10.1186/1478-4491-7-45 ; PMid:19500351 PMCid:PMC2697153

20. IMS Health. Libro blanco para las farmacéuticas en África. http://guinguinbali. com/index.php?lang=es\&mod=news\&task=view_news \&cat=2\&id=3484 . Accessed November 21, 2015

21. Holt T, Lahrichi M, Mina J, et al. Insights into Pharmaceuticals and Medical Products Africa: A Continent of Opportunity for Pharma and Patients. April 2015. http://www.mckinsey.com/ /media/mckinsey/dotcom/insights/ health $\% 20$ care/africa $\% 20-\% 20 a \% 20$ continent $\% 20$ of $\% 20$ opportunity $\% 20$ for $\% 20$ pharma $\% 20$ and $\% 20$ patients/pmp_africa_a_continent_of_ opportunity_for_pharma_and_patients.ashx. Accessed November 21, 2015.

22. World Health Organization (WHO). The role of the pharmacist in the health care system. Preparing the future pharmacist curricular development. 1997. Available at: http://www.who.int/medicinedocs/en/d/Js2214e/. Accessed November 21, 2015
23. Ordem dos Farmacêuticos de Angola (OFA). A formação ao serviço dos profissionais. Revista da Ordem dos Farmacêuticos de Angola. 2014;2:6.

24. Código Deontológico Farmacêutico. Associação de Farmacêuticos dos Países de Língua Portuguesa-AFPLP. Aprovado em Assambleia Geral, Cabo Verde, 14 de Março de 1999. http://www.ordemfarmaceuticosangola. org/profissaofarmaceutica.html. Accessed November 22, 2015.

25. Cumbana J. Farmacêuticos apostam numa formação integrada. Jornal Domingo Online. http://www.jornaldomingo.co.mz/index.php/nacional/5160farmaceuticos-apostam-numa-formacao-integrada. Accessed November 21, 2015.

26. Decreto Presidencial n. o 191/10 de 1 de setembro. Regulamento no exercisio da atividade farmacêutica. http://www.ordemfarmaceuticosangola. org/PDF/Regulamento\%20do\%20Exercicio\%20Farmaceutico.pdf. Accessed November 16, 2015.

27. Lista das Farmácias atualizada. Ordem dos Farmacêuticos de Angola. http:// www.ordemfarmaceuticosangola.org/PDF/Lista\%20das\%20Farmacia\%20 Actualizadas12.pdf. Accessed November 20, 2015.

28. Prestação de serviços pelas farmácias. Resolução AFPLP.http://www. ordemfarmaceuticosangola.org/PDF/Prestacao $\% 20$ de $\% 20$ Servicos $\% 20$ pelas\%20Farmacias_Resolucao\%20AFPLP.pdf. Accessed November 21, 2015.

\section{SUMMARY}

- In Angola to practice as a pharmacist, one needs a pharmacy degree.

- Universities and polytechnics comprise the Pharmacy Schools.

- Access and quality have been identified as the two main problems of the education system in Angola

- In Angola, there are no Accreditation Standards and Guidelines for Pharmacy Education.

- Ensuring high-quality pharmacy education is a major challenge.

\section{About Author}

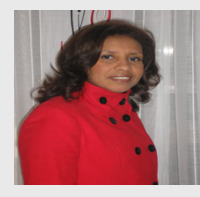

Alina M. Sánchez, PhD: Working as Pharmacology Professor at the Physiotherapy and Nursing School in Toledo, Universidad de Castilla La Mancha, Spain. Alina M. Sánchez has 40 paper publications, also has 4 books published. She received a FIP Award in 1999 to attend the World Pharmacy Education Congress. Currently, she is the Main Coordinator of the Project for the continuing professional development for pharmacists from Africa speaking-Portuguese countries. 